\title{
Genetics of headache and catechol-0-methyltransferase gene polymorphism
}

Published online: 26 April 2006

Headache is a common symptom, and can result from a variety of factors. Migraine is one of the most important types of headache, with its distinct pathophysiology, which has not been illuminated yet. However, it is apparent that that there is a genetic predisposition to migraine and much work has been performed to understand the genetic basis of this disease [1-4].

In the study by Hagen and coworkers, association between headache and Val158Met polymorphism in the catechol-O-methyltransferase (COMT) gene was investigated [5]. One of the most important features of this study is inclusion of a huge number of patients as well as control subjects, which makes the results reliable. This study is of utmost important for our understand- ing of the significance of COMT gene polymorphism both in migraineurs' and non-migraineurs' headaches. In addition, it is apparent that genetic predisposition to headache may differ between males and females. It is also apparent that the genetic basis of migraine and non-migraine headache is different, which will promote studies on genetic bases of headache. Understanding the molecular differences between different types of headache will change the way that we treat patients.

Yildirim A. Bayazit Department of Otolaryngology, Faculty of Medicine,

Gazi University, Besevler, Ankara, Turkey e-mail:bayazity@yahoo.com

\section{References}

1. Erdal ME, Herken H, Yilmaz M, Bayazit YA (2001) Association of the T102C polymorphism of 5HT2A receptor gene with aura in migraine. $\mathrm{J}$ Neurol Sci 188:99-101

2. Estevez M, Gardner KL (2004) Update on the genetics of migraine. Hum Genet 114:225-235
3. Lulli P, Trabace S, Morellini M, Cicciarelli G, Coloprisco G, Piane M, De Filippis S, Santi PG, Avramakou O, Ferlicca E, Martelletti P (2005) Cytotoxic T lymphocyte antigen 4 polymorphism $49(\mathrm{~A}>\mathrm{G})$ and migraine. J Headache Pain 6:188-190

4. Pietrobon D (2005) Function and disfunction of synaptic calcium channels: insights from mouse models. Curr Opin Neurobiol 15:257-265
5. Hagen K, Pettersen E, Stovner LJ, Skorpen F, Zwart JA (2006) The association between headache and Val158Met polymorphism in the catechol-O-methyltransferase gene. The HUNT Study. J Headache Pain 7:70-74 